\title{
CFD ANALYSIS OF HEAT TRANSFER ENHANCEMENT BY USING PASSIVE TECHNIQUE IN HEAT EXCHANGER
}

\author{
C Rajesh Babu and Santhosh Kumar Gugulothu \\ Assistant Professor, Department of Mechanical Engineering, GITAM University, \\ HYDERABAD, INDIA
}

\begin{abstract}
The heat transfer enhancement is very important many engineering applications to increase the performance of heat exchangers. The active techniques required external power like surface vibrations, electrical fields etc and the passive techniques are those which does not required any external power but the inserts are required to disturb the flow like tape inserts etc moreover literature survey says passive techniques gives more heat transfer rate without external power requirement by keeping different tape inserts. However CFD tool is very important and effective tool to understanding heat transfer applications. Computational heat transfer flow modelling is one of the great challenges in the classical sciences. By incorporating the inserts the heat transfer enhancement is increased due to its importance in different applications. By CFD modelling by taking concentric tube by considering with and without inserts we conclude that heat transfer enhancement by using ANSYS Fluent version 14.5.
\end{abstract}

\section{KEYWORDS}

Heat transfer, parallel flow heat exchanger, heat transfer agumentation, CFD Analysis, passive technique, Reynolds no, Nussult no, twisted tape insert.

\section{INTRODUCTION}

Heat exchanger is a piece of equipment built for efficient heat transfer from one medium to another. They facilitate the exchange of heat between two fluids that are at different temperatures while keeping them from mixing with each other. Different applications of heat exchanger are condensers, evaporators, boilers conditionation and refrigeration etc. Heat exchanger is used in automobile radiators and coolers. Heat exchangers are also abundant in chemical and process industries. We will consider only the more common types here for discussing some analysis and design methodologies. Heat exchangers are popular used in industrial and engineering applications. The design procedure of heat exchangers is quite complicated, as it needs exact analysis of heat transfer rate, efficiency and pressure drop apart from issues such as long- term performance and the economic aspect of the equipment. By incorporating different techniques we conclude that heat transfer coefficient increases with the cost of pressure drop. Heat transfer enhancement techniques are classified as follows 


\subsection{Passive Techniques:}

Passive techniques are geometrical change or with disturbing the fluid by keeping inserts. They promote higher heat transfer coefficients by disturbing or altering the existing flow behaviour (except for extended surfaces) which also leads to increase in the pressure drop. Heat transfer augmentation achieved by following

Treated Surfaces: Treated surfaces are applicable primarily in two-phase heat transfer, and they consist of a variety of structured surfaces (continuous or discontinuous integral surface roughness or alterations) and coatings. In the event that this treatment provides a "roughness" to the surface, its size (normal protrusion to the surface) is not large enough to influence single-phase forced convection

Rough surfaces: Structured roughness can be integral to the surface, or the protuberances can be introduced in the form of wire-coil-type inserts. The former can be produced by machining (e.g., knurling, threading, grooving), forming, casting, or welding, and the resulting surface proturberances or grooves can be two dimensional or discrete three-dimensional in their geometrical arrangement

Extended surfaces: Extended or finned surfaces are perhaps the most widely used and researched of all enhancement techniques. Enhanced heat transfer from finned surfaces by buoyancy-driven natural or free convection has been considered primarily for cooling of electrical and electronic devices and for hot-water baseboard room heaters. building/room heating equipment, the use of baseboard heaters has declined considerably; in fact, this practice is close to being discontinued.

Swirl flow devices: Swirl flow devices generally consist of a variety of tube inserts, geometrically varied flow arrangements, and duct geometry modifications that produce secondary flows. Typical examples of each of these techniques include twisted-tape inserts, periodic tangential fluid injection, and helically twisted tubes.

Coiled tubes: A coiled or curved tube has long been recognized as a swirl-producing flow geometryThe secondary fluid motion is generated essentially by the continuous change in direction of the tangential vector to the bounding curved surface of the duct, which results in the local deflection of the bulk flow velocity vector. 
International Journal of Recent advances in Mechanical Engineering (IJMECH) Vol.4, No.3, August 2015

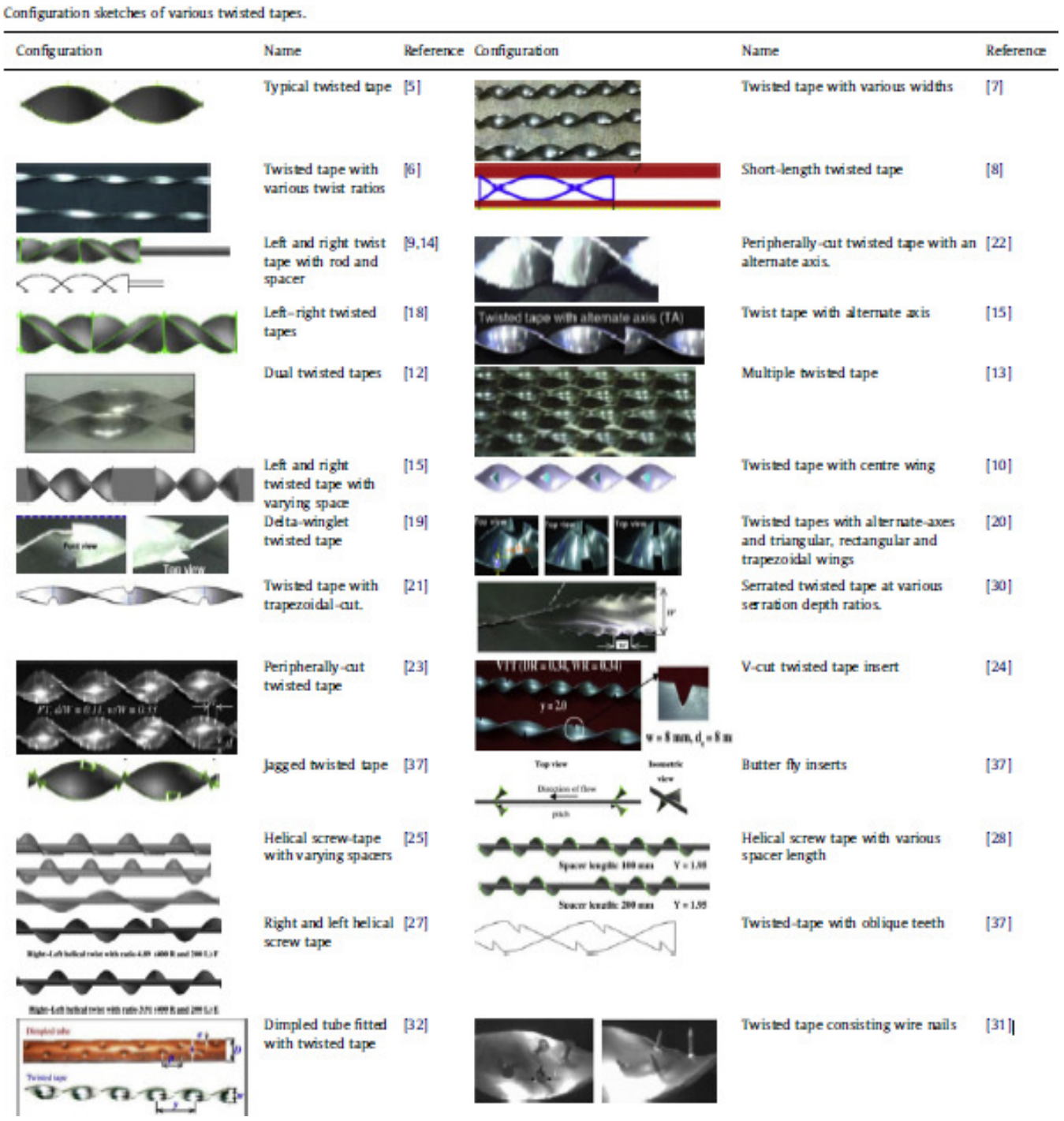

Table 1. Configuration sketches of various twisted tapes.

By incorporating helical tape inserts as literature survey says there is a heat transfer enhancement. For the experimental set up by Reducing width of the helical twisted tape inserts with ID of inside tube $(\mathrm{W} / \mathrm{di}=0.675))$ are shown in Table 1 . Configuration sketches of various twisted tapes.

\section{METHODOLOGY}

Following methodology used to evaluate performance by using CFD analysis.

- Identification of flow domain

- Geometry Modeling.

- Grid generation.

- Specification of boundary Conditions.

- Selection of solver parameters and

- Convergence criteria.

- Results and post processing. 


\subsection{Modelling}

Heat exchanger is modelled using CATIA V5 software. It is an assembly of all the parts. A concentric tube heat exchanger (with twisted tape), heat exchanger (without inserting any twisted tape) is modelled according to the dimensions of practically available heat exchanger. Heat exchanger with twisted tape

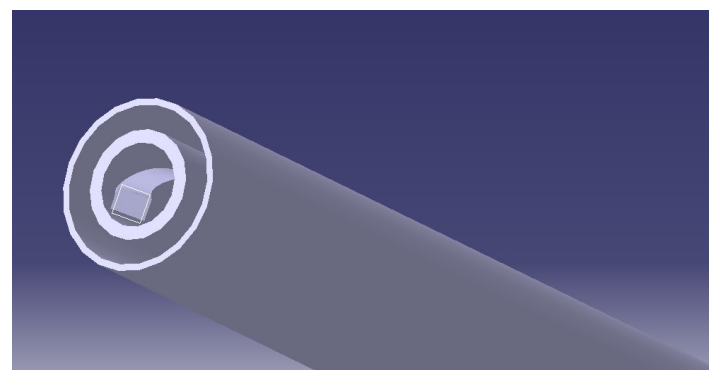

Figure 1. Heat exchanger with twisted tape

\section{SpecificationsHeat exchanger}
Outer diameter of the outer tube
: $39 \mathrm{~mm}$
Inner diameter of the outer tube
$: 36 \mathrm{~mm}$
Outer diameter of the inner tube
$: 25 \mathrm{~mm}$
Inner diameter of the outer tube
$: 19 \mathrm{~mm}$
Length of the heat exchanger
$: 200 \mathrm{~mm}$

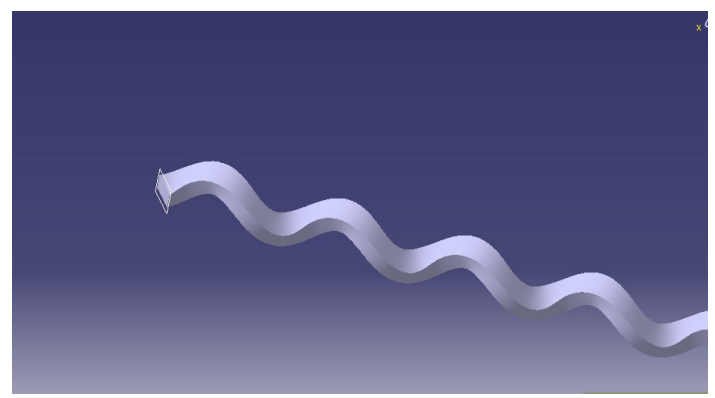

Figure 2.twisted tape

Twisted tape

Length of the twisted tape

Pitch of the twisted tape

Cross section of twisted tape
: $200 \mathrm{~mm}$

: $40 \mathrm{~mm}$

: rectangular $(7 * 5)$ 


\section{Heat exchanger without twisted tape}

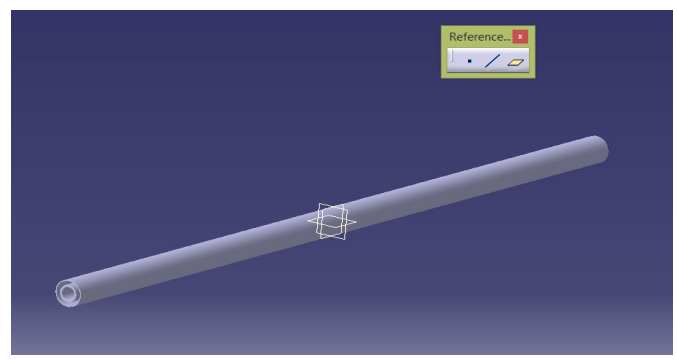

Figure 3.Heat exchanger without twisted tape

\section{Specifications Heat exchanger}

$\begin{array}{ll}\text { Outer diameter of the outer tube } & : 39 \mathrm{~mm} \\ \text { Inner diameter of the outer tube } & : 36 \mathrm{~mm} \\ \text { Outer diameter of the inner tube } & : 25 \mathrm{~mm} \\ \text { Inner diameter of the outer tube } & : 19 \mathrm{~mm} \\ \text { Length of the heat exchanger } & : 200 \mathrm{~mm}\end{array}$

\subsection{Meshing}

The designed heat exchanger is imported into the ANSYS Workbench. It is meshed by using mesh module. Meshing is done as discussed in the previous units. In this regard 3D unstructured meshing is used to mesh the object regard 3D unstructured meshing is used. The following fig shows the meshing parts.

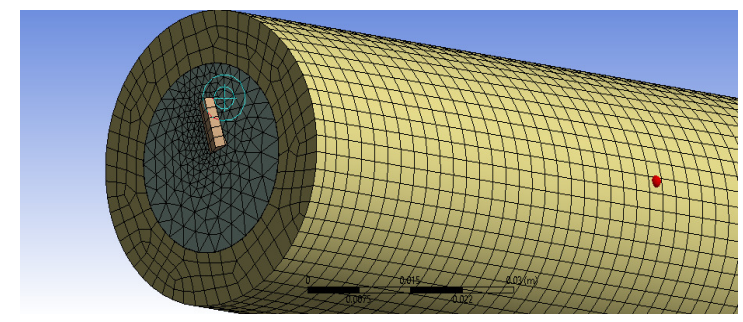

Figure 4.Meshed heat exchanger with twisted tape

\section{Details of meshing}

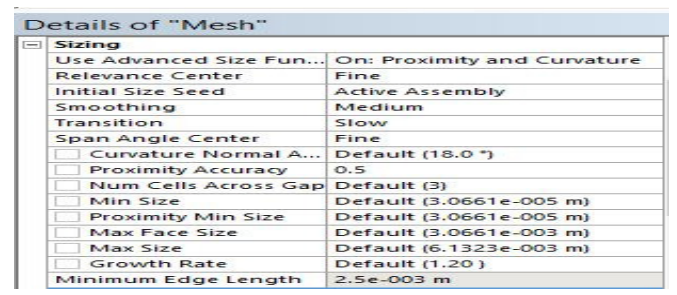

Table 1. Meshing details

Nodes $\quad: 37366$

Elements $\quad: 105486$ 


\subsection{Analysis}

After the completion of meshing the design is opened in ANSYS Fluent. In fluent boundary conditions are given as per requirement and the solution is initialized and calculations are iterated. After the calculation is converged the contours are to be plotted.

\section{Boundary conditions:}

- Fluid domain is to be specified

- Temperature

At inlet

Hot fluid - water $(335 \mathrm{k})$

Cold fluid - water (300k) at normal pressure

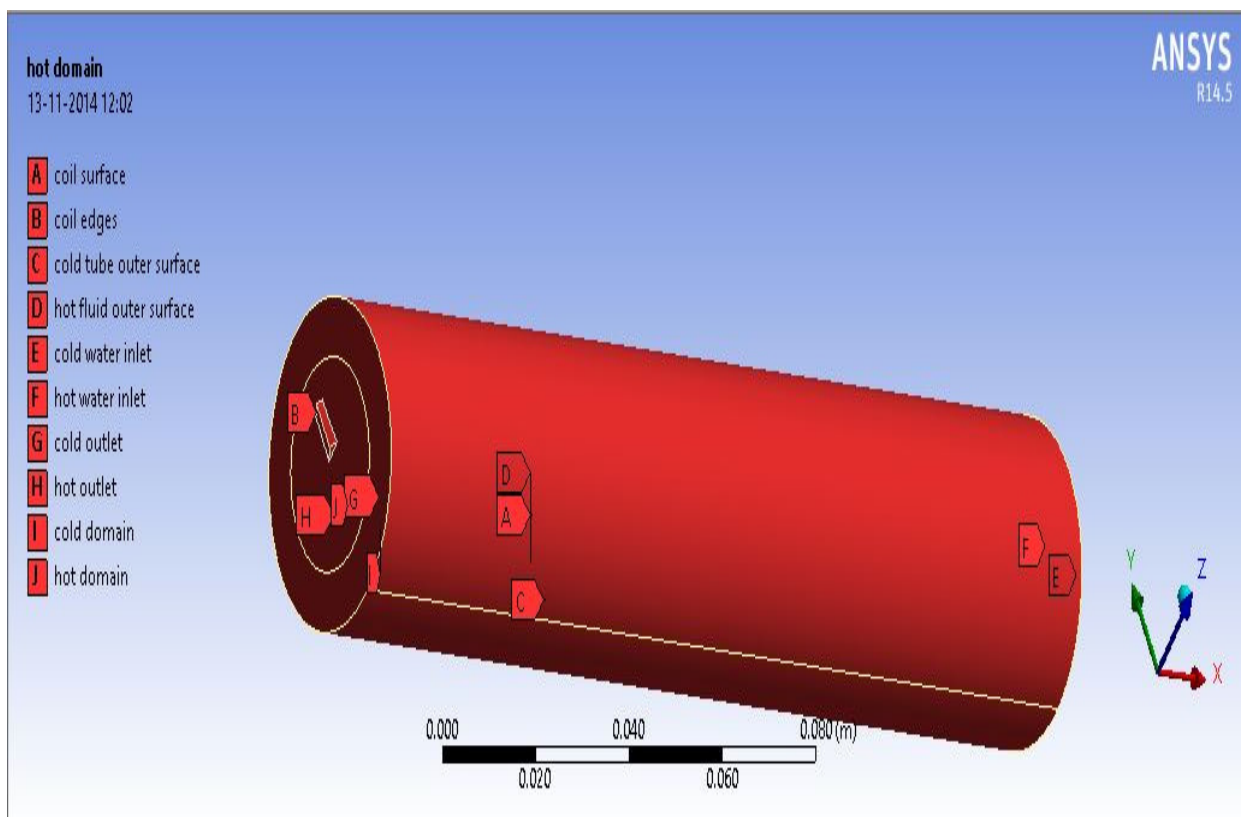

Figure 5. Boundaries of the heat exchanger

In the analysis report the mainly Reynolds number, pressure, velocity, temperature contour to be viewed. The results obtained are to be tabulated.

Boundary specifications

Coil surface

: wall

Coil edges

: wall

Cold tube outer surface

: wall

Hot tube outer surface

: wall

Cold water inlet

: velocity inlet

Hot water inlet

: velocity inlet

Cold water outlet

: pressure outlet

Hot water outlet

: pressure outlet

Cold domain

: mass flow

Hot domain

: mass flow 


\subsection{Reynolds number variation}

\section{Heat exchanger with twisted tape}

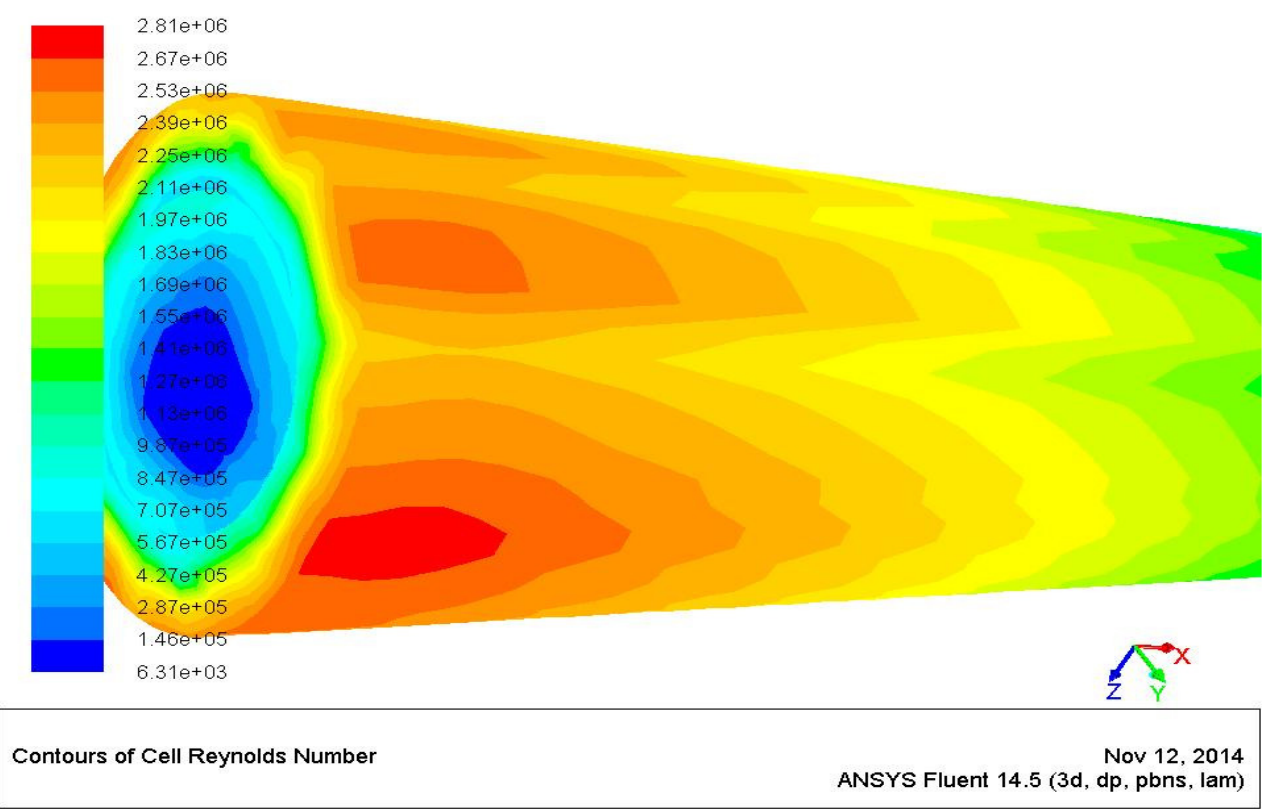

Figure 6. Reynolds number variation in heat exchanger with twisted tape
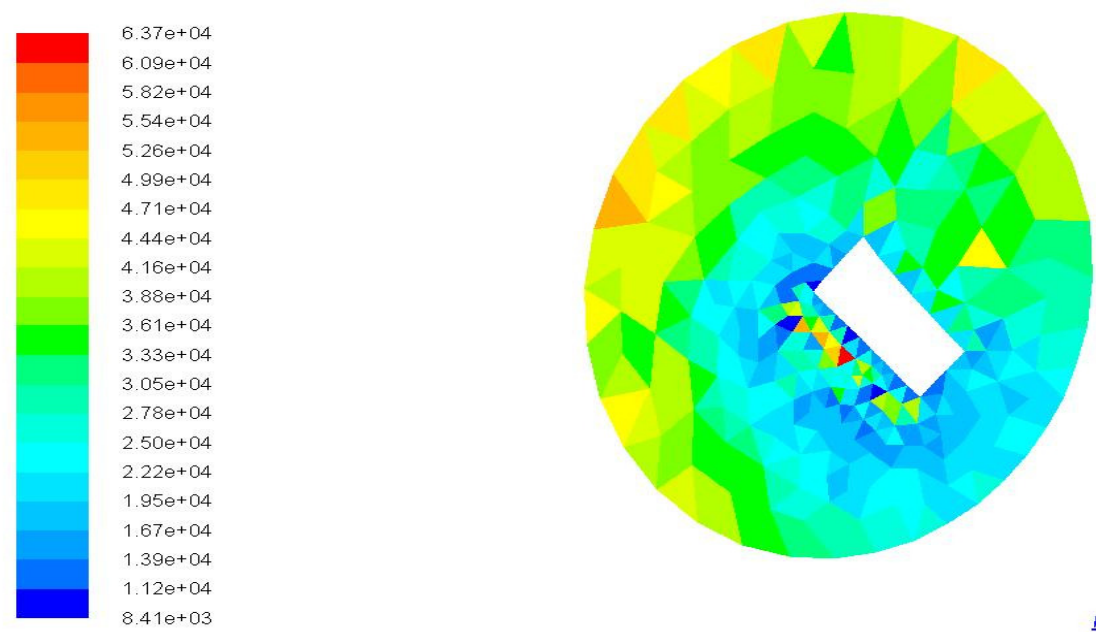

$1.12 e+04$

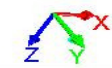

Contours of Cell Reynolds Number

Figure 7. Reynolds number at inlet in heat exchanger with twisted tape 


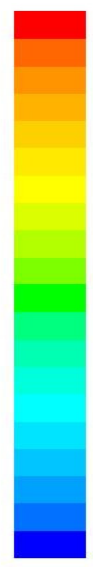

$1.03 e+06$
$9.79 e+05$
$9.28 e+05$
$8.77 e+05$
$8.25 e+05$
$7.74 e+05$
$7.22 e+05$
$6.71 e+05$
$6.20 e+05$
$5.68 e+05$
$5.17 e+05$
$4.66 e+05$
$4.14 e+05$
$3.63 e+05$
$3.12 e+05$
$2.60 e+05$
$2.09 e+05$
$1.58 e+05$
$1.06 e+05$
$5.50 e+04$
$3.70 e+03$

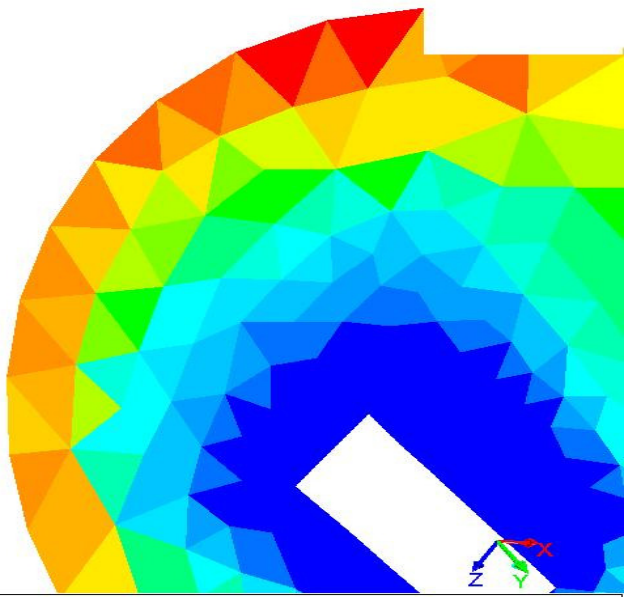

Contours of Cell Reynolds Number

Nov 12, 2014 ANSYS Fluent 14.5 ( $3 \mathrm{~d}$, dp, pbns, lam)

Figure 8. Reynolds number at out in heat exchanger with twisted tape

In the above figures we can observe that the Reynolds number is increasing from inlet of the heat exchanger to the outlet of the heat exchanger. This is because of the reason that, during the flow of fluid over the twisted tapes a disturbance is created in the flow, thus turbulence is created .This results in the increase of the Reynolds number.

\section{Heat exchanger without twisted tape}

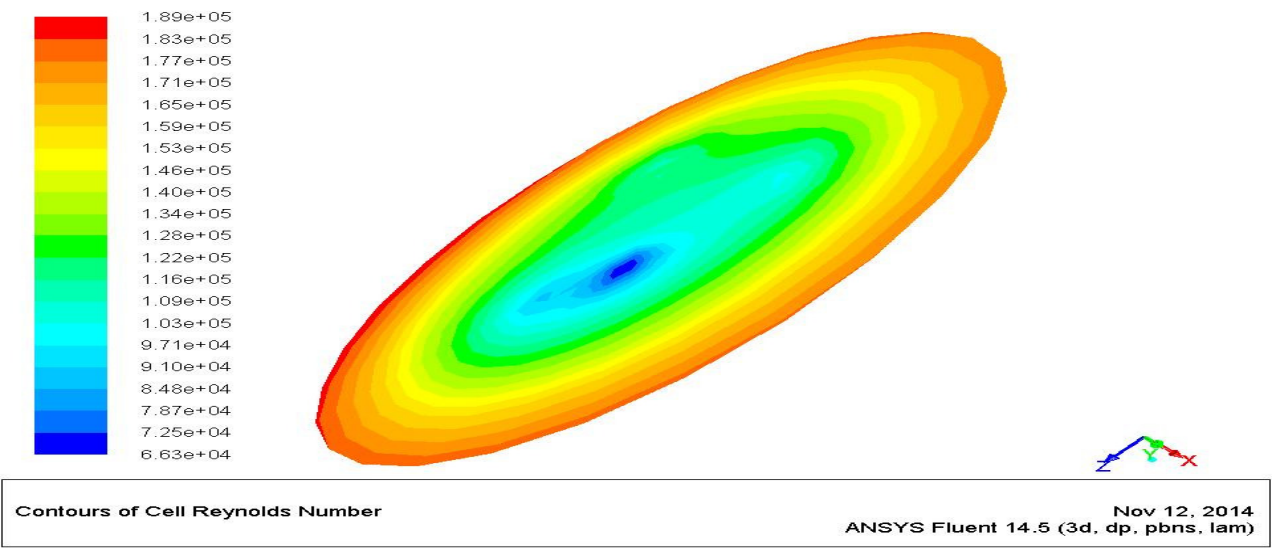

Figure 9.Reynolds number at inlet in heat exchanger without twisted tape 


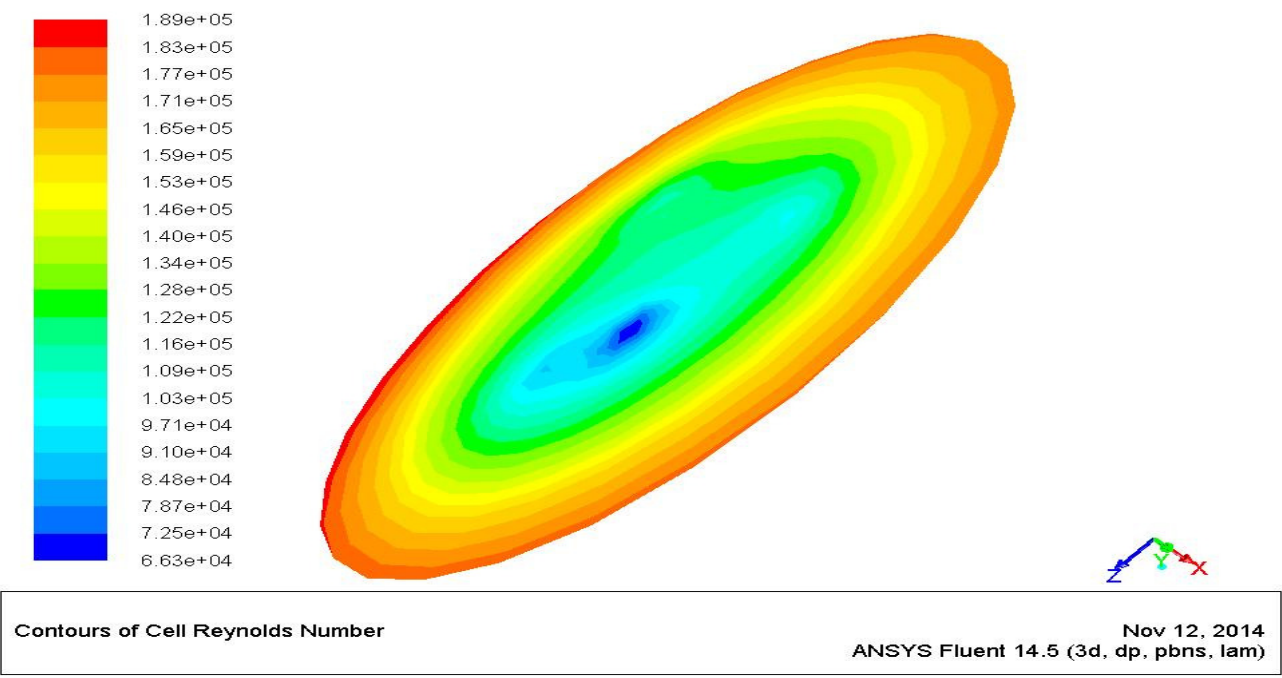

Figure 10.Reynolds number at outlet in heat exchanger without twisted tape

Figs $9 \& 10$ shows the Reynolds number of the hot fluid at the inlet and outlet of the heat exchanger . we observe that there is not much difference in the values, they remain almost constant. This is due to no turbulance in the flow.

\section{Velocity vector}

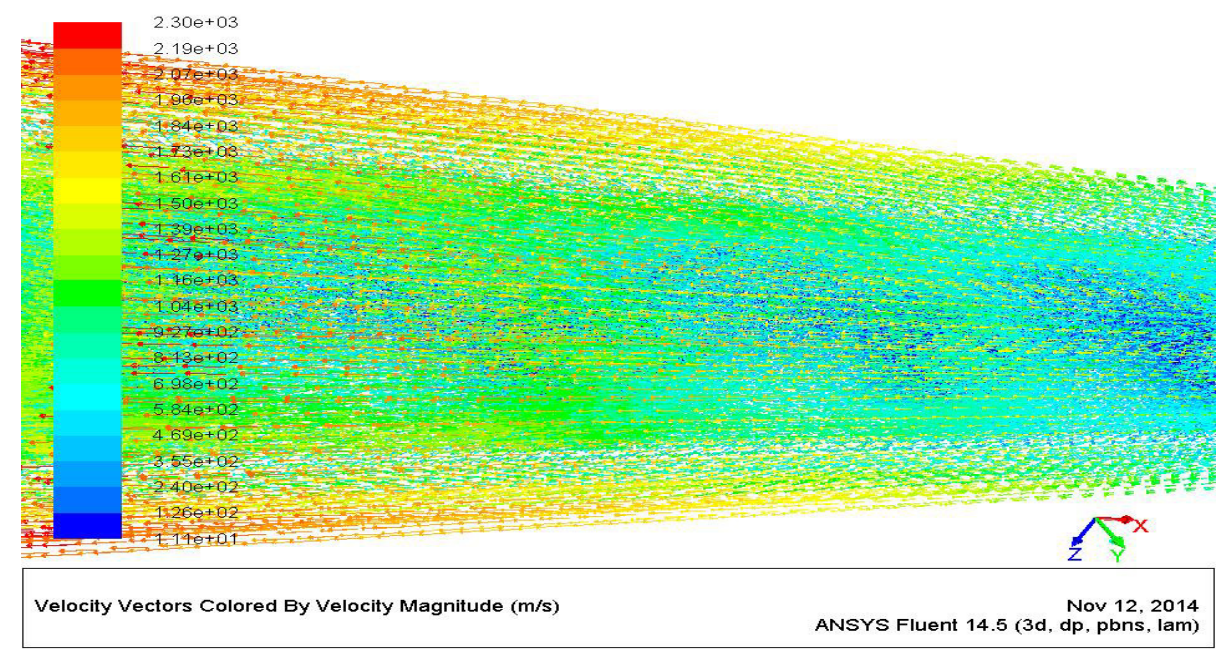

Figure 11.velocity vector of heat exchanger with twisted tape

The above fig 11 shows the velocity \& direction of the fluid elements during the flow in heat exchanger (with twisted tape).We can observe that there is a rise in velocity of the fluid elements when moving from inlet to the outlet .This is due to the swirl created by the twisted tape. 


\section{RESULTS AND DISCUSSION}

The results showing for different velocities with different contours are plotted The results obtained are tabulated as shown.

With twisted tape

At $\mathrm{V}=33.63 \mathrm{~m} / \mathrm{s}$

\begin{tabular}{|l|l|l|l|l|}
\hline Parameters & $\begin{array}{l}\text { Hot fluid } \\
\text { inlet }\end{array}$ & $\begin{array}{l}\text { Hot fluid } \\
\text { Outlet }\end{array}$ & $\begin{array}{l}\text { Cold fluid } \\
\text { inlet }\end{array}$ & $\begin{array}{l}\text { Cold fluid } \\
\text { outlet }\end{array}$ \\
\hline Pressure(pas) & $2.98 \mathrm{e} 8$ & $2.23 \mathrm{e} 6$ & $2.6 \mathrm{e} 7$ & $4.3 \mathrm{e} 6$ \\
\hline Reynolds no & $3.61 \mathrm{e} 4$ & $6.28 \mathrm{e} 5$ & $9.12 \mathrm{e} 4$ & $1.17 \mathrm{e} 6$ \\
\hline
\end{tabular}

Table 2. parameters at $\mathrm{V}=33.63 \mathrm{~m} / \mathrm{s}$

$\mathrm{V}=67.2 \mathrm{~m} / \mathrm{s}$

\begin{tabular}{|l|l|l|l|l|}
\hline Parameter & $\begin{array}{l}\text { Hot fluid } \\
\text { inlet }\end{array}$ & Hot fluid outlet & $\begin{array}{l}\text { cold fluid } \\
\text { inlet }\end{array}$ & Cold fluid outlet \\
\hline Pressure(pa) & $1.17 \mathrm{e} 9$ & $1.35 \mathrm{e} 7$ & $2.8 \mathrm{e} 9$ & $9.79 \mathrm{e} 7$ \\
\hline Reynolds no & $6.84 \mathrm{e} 4$ & $1.39 \mathrm{e} 6$ & $1.57 \mathrm{e} 5$ & $2.80 \mathrm{e} 6$ \\
\hline
\end{tabular}

Table 3.parameters at $\mathrm{V}=67.2 \mathrm{~m} / \mathrm{s}$

$\mathrm{V}=100.8 \mathrm{~m} / \mathrm{s}$

\begin{tabular}{|l|l|l|l|l|}
\hline Parameter & Hot fluid inlet & Hot fluid outlet & Cold fluid inlet & $\begin{array}{l}\text { Cold fluid } \\
\text { outlet }\end{array}$ \\
\hline Pressure(pa) & $3.15 \mathrm{e} 9$ & $3.1 \mathrm{e} 8$ & $6.3 \mathrm{e} 9$ & $6.2 \mathrm{e} 8$ \\
\hline Reynolds no & $4.35 \mathrm{e} 5$ & $4.6 \mathrm{e} 6$ & $1.27 \mathrm{e} 6$ & $1.38 \mathrm{e} 6$ \\
\hline
\end{tabular}

Table 4. Parameters at $\mathrm{V}=100.8 \mathrm{~m} / \mathrm{s}$

Without twisted tape

At $\mathrm{V}=33.63 \mathrm{~m} / \mathrm{s}$

\begin{tabular}{|l|l|l|l|l|}
\hline Parameters & $\begin{array}{l}\text { Hot fluid } \\
\text { inlet }\end{array}$ & Hot fluid outlet & Cold fluid inlet & Cold fluid outlet \\
\hline Pressure & $1.02 \mathrm{e} 5 \mathrm{pas}$ & $1.01 \mathrm{e} 5 \mathrm{pas}$ & $1.01 \mathrm{e} 5 \mathrm{pas}$ & $1 \mathrm{e} 5 \mathrm{pas}$ \\
\hline
\end{tabular}



Reynolds no
6.75 e 4
$6.76 \mathrm{e} 4$
$6.75 \mathrm{e} 4$
$6.76 \mathrm{e} 4$

At $\mathrm{V}=67.2 \mathrm{~m} / \mathrm{s}$

Table 5. parameters at $\mathrm{V}=33.63 \mathrm{~m} / \mathrm{s}$

\begin{tabular}{|l|l|l|l|l|}
\hline Parameters & $\begin{array}{l}\text { Hot fluid } \\
\text { inlet }\end{array}$ & $\begin{array}{l}\text { Hot fluid out } \\
\text { let }\end{array}$ & $\begin{array}{l}\text { ssCold fluid } \\
\text { inlet }\end{array}$ & $\begin{array}{l}\text { Cold fluid } \\
\text { outlet }\end{array}$ \\
\hline Pressure(pas) & $1.03 \mathrm{e} 5$ & $1.01 \mathrm{e} 5$ & $1.06 \mathrm{e} 5$ & $1.01 \mathrm{e} 5$ \\
\hline Reynolds no & $1.28 \mathrm{e} 5$ & $1.28 \mathrm{e} 5$ & $1.26 \mathrm{e} 5$ & $1.26 \mathrm{e} 5$ \\
\hline
\end{tabular}

Table 6. parameters at $\mathrm{V}=67.2 \mathrm{~m} / \mathrm{s}$

$\mathrm{V}=100.8 \mathrm{~m} / \mathrm{s}$

\begin{tabular}{|l|l|l|l|l|}
\hline Parameters & Hot fluid inlet & Hot fluid outlet & $\begin{array}{l}\text { Cold fluid } \\
\text { inlet }\end{array}$ & $\begin{array}{l}\text { Cold fluid } \\
\text { outlet }\end{array}$ \\
\hline Pressure(pas) & $1.05 \mathrm{e} 5$ pas & $9.98 \mathrm{e} 5$ & $9.27 \mathrm{e} 4$ & $9.2 \mathrm{e} 4$ \\
\hline Reynolds no & $2.01 \mathrm{e} 5$ & $2.03 \mathrm{e} 5$ & $1.92 \mathrm{e} 5$ & $1.94 \mathrm{e} 5$ \\
\hline
\end{tabular}

Table 7. parameters at $\mathrm{V}=100.8 \mathrm{~m} / \mathrm{s}$

After tabulating the results they are compared in both cases. It is observed that the Reynolds number varies largely between inlet and outlet of the heat exchanger in the case of heat exchanger with twisted tape, whereas in heat exchanger without twisted tape Reynolds number remains constant.

When we are concern about the pressure, pressure drop is larger in with twisted tape than without twisted tape. Our concern is about the enhancement of heat transfer so we can ignore the pressure drop.

\subsection{Validation}

By using the equation Dittus-Boelter Reynolds number is directly proportional to the nusselt number correlate the results

$$
\begin{array}{ll}
\mathrm{Nu}=0.023(\mathrm{Re})^{\wedge} 0.8 \mathrm{pr}^{\mathrm{n}} & \mathrm{Nu}=\text { Nusselt number } \\
\mathrm{n}=0.4 \text { for heating fluids } & \mathrm{Re}=\text { Reynolds number } \\
\mathrm{n}=0.3 \text { for cooling liquids } & \mathrm{pr}=\text { prandtl number } \\
& \mathrm{h}=\text { heat transfer coefficient } \\
& \Delta \mathrm{t}=\text { change in temperature }
\end{array}
$$

From the equation above we conclude that as Reynolds number increases Nusselt number also increases. We have the formula to validate 


$$
\begin{aligned}
& \mathrm{h}=\left(\mathrm{Nu}^{*} \mathrm{~K}\right) / \mathrm{l} \\
& \mathrm{Q}=\mathrm{h}^{*} \mathrm{a}^{*} \Delta \mathrm{t}
\end{aligned}
$$

So , as Nusselt number increases the heat transfer coefficient also increases, as heat transfer coefficient increases the heat transfer enhancement is obtained.

\section{CONCLUSIONS}

CFD analysis is carried out by taking double pipe heat exchanger with cold and hot fluids with different boundary conditions by incorporating helical tape inserts .It can be concluded as follows: By using passive techniques that is by inserting helical tape inserts the heat transfer enhancement increased by $10-15 \%$ with the cost of reasonable allowable pressure drop .In this report we achieved enhancement of heat transfer effectively.

Future work may be extended to:

- Material should be changed to Aluminium to copper or which is having high thermal conductivity materials

- Combination of techniques may be used to enhancement of heat transfer coefficient by compound techniques.

- Reduce the width of helical tape inserts with low Reynolds number.

- By varying low Reynolds numbers check the Heat transfer enhancement coefficient

\section{REFERENCES}

[1] Al-Fahed S, and Chakroun W, 1996. Effect of tube -tape clearance on heat transfer for fully developed turbulent flow in a horizontal isothermal tube, Int. J. Heat Fluid Flow, Vol. 17, No. 2, pp. 173-178.

[2] Al-Fahed S, Chamra L.M, and Chakroun W, 1998. Pressure drop and heat transfer comparison for both microfin tube and twistedtape inserts in laminar flow, Experimental Thermal Fluid Science, Vol. 18 , No. 4, pp. 323-333.

[3] Akhavan-Behabadi M.A, Ravi Kumar, Mohammadpour .A and Jamali-Asthiani .M, 2009. Effect of twisted tape insert on heat transfer and pressure drop in horizontal evaporators for the flow of R-134a, International Journal of Refrigeration, Vol. 32, No. 5, pp. 922-930.

[4] Akhavan-Behabadi M. A., Ravi Kumar and A. Rajabi-Najar, 2007. Augmentation of heat transfer by twisted tape inserts during condensation of R-134a inside a horizontal tube, Heat and Mass Transfer, Vol. 44, No. 6, pp. 651-657

[5] S.K.Saha A.Dutta " Thermo hydraulic study of laminar swirl flow through a circular tube fitted with twisted tapes" Trans. ASME Journal of heat transfer June 2001, Vol-123/ pages 417-427.

[6] Watcharin Noothong, Smith Eiamsa-ard and Pongjet Promvonge" Effect of twisted tape inserts on heat transfer in tube" 2nd joint international conference on "sustainable Energy and Environment 2006" Bangkok, Thiland.

[7] Paisarn Naphon "Heat transfer and pressure drop in the horizontal double pipes with and without twisted tape insert" 2005 Elsevier Ltd.

[8] Smith Eiamsa-ard , Chinaruk Thianpong, Pongjet Promvonge " Experimental investigation of heat transfer and flow friction in a Circular tube fitted with regularly spaced twisted tape elements" International Communications in Heat and Mass Transfer Vol. 33, Dec 2006.

[9] Ashis K. Mazumder, Sujoy K. Saha "Enhancement of Thermo hydraulic Performance of Turbulent Flow in Rectangular and Square Ribbed Ducts With Twisted-Tape Inserts" Journal of Heat Transfer AUGUST 2008, Vol. 130.

[10] M. Siddique, A.-R. A. Khaled, N. I. Abdulhafiz, and A. Y. Boukhary" Review Article Recent Advances in Heat Transfer Enhancements: A Review Report" International Journal of Chemical Engineering Volume 2010 (2010), Article ID 106461, 28 pages 
International Journal of Recent advances in Mechanical Engineering (IJMECH) Vol.4, No.3, August 2015

\section{AUTHORS}

C Rajesh Babu , Assistant Professor in the Department of Mechanical Engineering, GITAM University, Hyderabad, India.

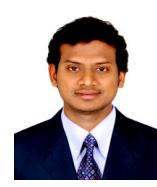

Santhosh Kumar Gugulothu, Assistant Professor, Department of Mechanical Engineering, GITAM University, Hyderabad, India. 